\title{
An Updated Dose Assessment for Late Jute Seed Production
}

\author{
Md Saheb Ali, Md Marfudul Hoque, Sarmin Shahanaz, Md Nasimul Gani, Md Mahbubul Islam*
}

Agronomy Division, Bangladesh Jute Research Institute, Dhaka, Bangladesh

\section{Email address:}

mahbub_agronomy@yahoo.com (Md M. Islam)

${ }^{*}$ Corresponding author

\section{To cite this article:}

Md Saheb Ali, Md Marfudul Hoque, Sarmin Shahanaz, Md Nasimul Gani, Md Mahbubul Islam. An Updated Dose Assessment for Late Jute Seed Production. American Journal of Plant Biology. Vol. 4, No. 3, 2019, pp. 34-39. doi: 10.11648/j.ajpb.20190403.13

Received: September 15, 2019; Accepted: September 29, 2019; Published: October 11, 2019

\begin{abstract}
Jute seed scarcity in Bangladesh is a major problem for jute growers as jute and allied fibres are the most economic product for the country. Seed is a critical input for jute crop as it is not possible to get both the seed and fibre from the same crop. Organized late jute seed production is lacking in the whole country of Bangladesh. Therefore, updating seed production potential of jute was tested under Jute experimental station of Bangladesh Jute Research Institute. Following the strategy, additional nutrient response to O-9897 and O-72 (Chorcorus olitorius L.) in late jute seed production was assessed in Jute Agriculture Experimental Station (JAES), Manikganj, Bangladesh during the late Jute season. A highly significant effect was observed for plant height, number of branches/plant, number of pods/plant, number of seeds/pod and seed yield with the application of increasing doses of NPK fertilizer. Significantly high seed yields were found with the application of additional $25 \%$ NP or $25 \%$ NPK with existing recommended doses of fertilizer for late jute seed production for the varieties.
\end{abstract}

Keywords: Late Jute Seed Production, O-9897, O-72, Fertilizer

\section{Introduction}

In Bangladesh, annually the farmers require about 30 thousand tons of seeds annually. Many jute farmers use to produce jute crops by their own seeds to meet their requirements but such seeds are of poor quality. One of the most important problems for jute production in Bangladesh is the nonavailability of quality seed at proper time of sowing. Only $30 \%$ quality jute seed is supplied by different national agencies but the rest amount of quality seed is yet to be managed to supply.

The conventional method of jute seed production is not enough at all to meet the demand of the farmers. The jute growers in Bangladesh generally do not grow a separate jute crop for seed production as it requires long time from March to December which hampers transplant aman rice and rabi (winter) crops. The farmers usually keep a small portion of the crop at one corner of the field to produce seed and rest of the crop is harvested for fibre. This traditional system of seed production is characterized by low yield and poor quality of seed. So, the country has been facing acute shortage of quality jute seed every year. Quality seed of an improved variety itself provide 20 percent additional yield of the crop [1].
Nutrient management is the most important factor for jute seed quality and yield ant it is extensively studied [2-11]. Therefore, appropriate technology to produce quality seed is a must, to increase the production of jute in Bangladesh. Late jute seed production technology can solve this problem. To overcome jute seed problems and to ensure supply of required quality seeds, Bangladesh Jute Research Institute has been advocation late or off season seed production for higher seed yield and economic return, which to be sown in the month of August and September and harvested in December and January and the crops are subjected to favourable environmental stimuli [12-14]. With these facts in mind, the present piece of work was, therefore, undertaken to find the comparative merits of yield and return of late jute seed production update.

\section{Materials and Methods}

The experiments were conducted at the JAES, Manikganj of Bangladesh Jute Research Institute with eight selective treatments in randomized complete block design with three replications. The unit plot size was $3.0 \mathrm{~m} \times 3.0 \mathrm{~m}$, space between plots, blocks and around the field was $1.0 \mathrm{~m}$. There 
were $20 \mathrm{~cm}$ deep drain around each plot, block and around whole plot to drain out excess rain water. Experiment was set up in the month of august with the variety O-9897 \& O-72. Total amount of PKS from TSP, MoP and Gypsum were applied to the plot at the time of sowing as per treatment. Total amount of $\mathrm{N}$ from urea as per treatment were applied in three equal splits-one at sowing-one at 20-25 DAS and rest at 40-45 DAS. The treatments were as follows: $\mathrm{T}_{1}=100 \% \mathrm{NPKS}$ (FRG2012, BARC); $\mathrm{T}_{2}=\mathrm{T}_{1}+25 \% \mathrm{~N} ; \mathrm{T}_{3}=\mathrm{T}_{1}+25 \% \mathrm{NP} ; \mathrm{T}_{4}=$ $\mathrm{T}_{1}+25 \% \mathrm{NK} ; \mathrm{T}_{5}=\mathrm{T}_{1}+25 \% \mathrm{PK} ; \mathrm{T}_{6}=\mathrm{T}_{1}+25 \% \mathrm{NPK} ; \mathrm{T}_{7}=$ $75 \%$ of $\mathrm{T}_{1} ; \mathrm{T}_{8}=$ Control. Weeding, thinning, insect pest and disease management were done in time. The experiments were harvested within January of the following year when 80 percent of the pods were brown. During the time of harvest, plant population was recorded. The plant height, number of branches per plant, number of pods per plant, seeds per pod, and seed yield were recorded from each plot. All collected data were analyzed statistically following the ANOVA technique and the means were adjudged by DMRT [15].

\section{Results and Discussion}

Plant population: There was no significant variation in plant population with the increasing dose of nitrogen, phosphorus and potassium fertilizer application on late jute seed production (data not shown). The application of additional fertilizers did not have any significant effect on the number of plants $/ \mathrm{m}^{2}$. Reported previously [16]

Plant height: Significant effect of increasing dose of fertilizer application on plant height was observed. The highest significant plant height was observed with the application of $\mathrm{T}_{3}\left(\mathrm{~T}_{1}+25 \% \mathrm{NP}\right)$ which was identical with $\mathrm{T}_{6}$

\section{$\left(\mathrm{T}_{1}+25 \% \mathrm{NPK}\right)$.}

Number of branches/plant: Number of branches/plant increased significantly with increasing doses of $\mathrm{N}$ fertilizer. Application of increasing doses of $\mathrm{P}$ and $\mathrm{K}$ in combination or with $\mathrm{N}$ fertilizer affects the number of branches/plant significantly. Highest number of branches/plant were observed with $\mathrm{T}_{6}\left(\mathrm{~T}_{1}+25 \% \mathrm{NPK}\right)$ and $\mathrm{T}_{3}\left(\mathrm{~T}_{1}+25 \% \mathrm{NP}\right)$.

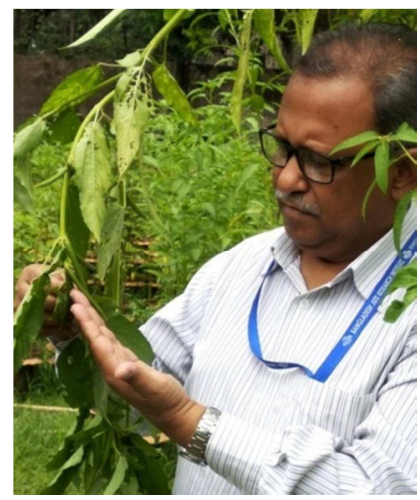

Figure 1. Experimental plots observation.

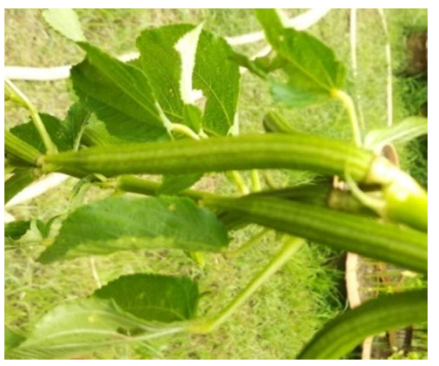

Figure 2. Seedcapsule and maturity observation.
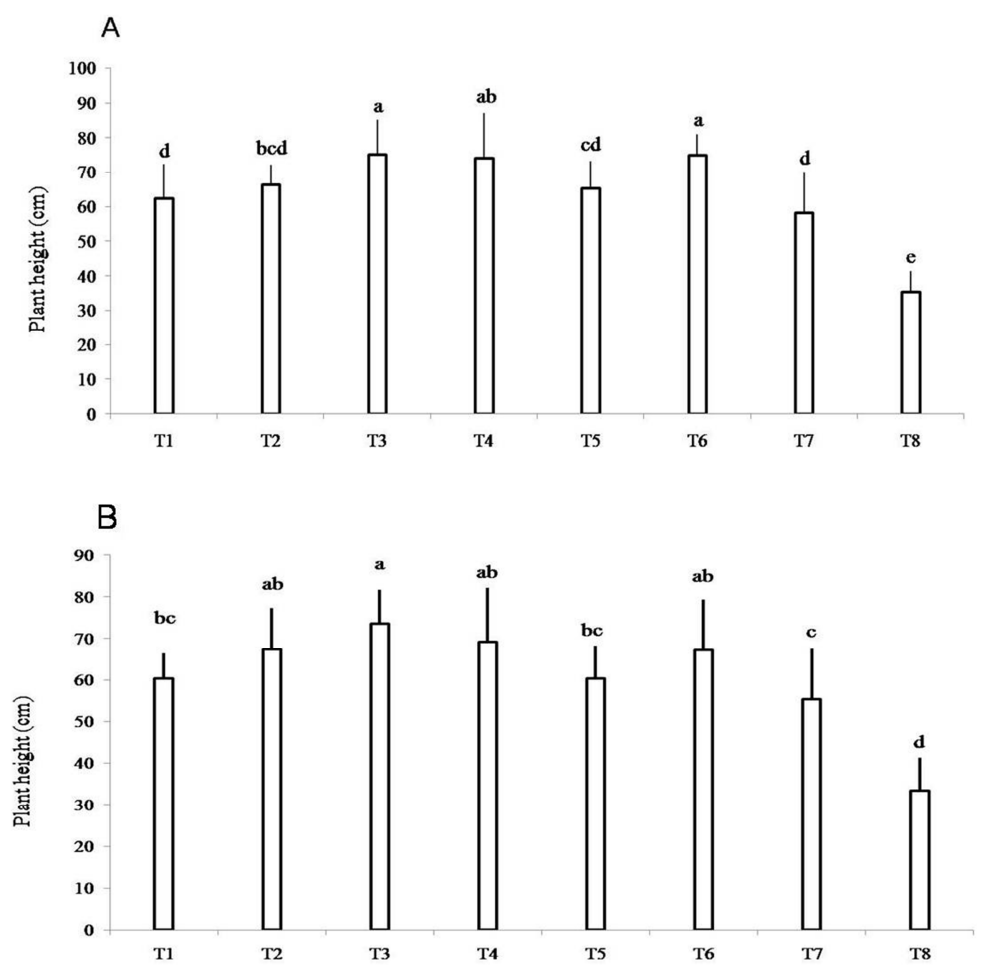

Figure 3. Plant heightobservation by different treatments.(A) O-9897 (B) O-72. The results are expressed as the mean \pm S. E. M and DMRT. 

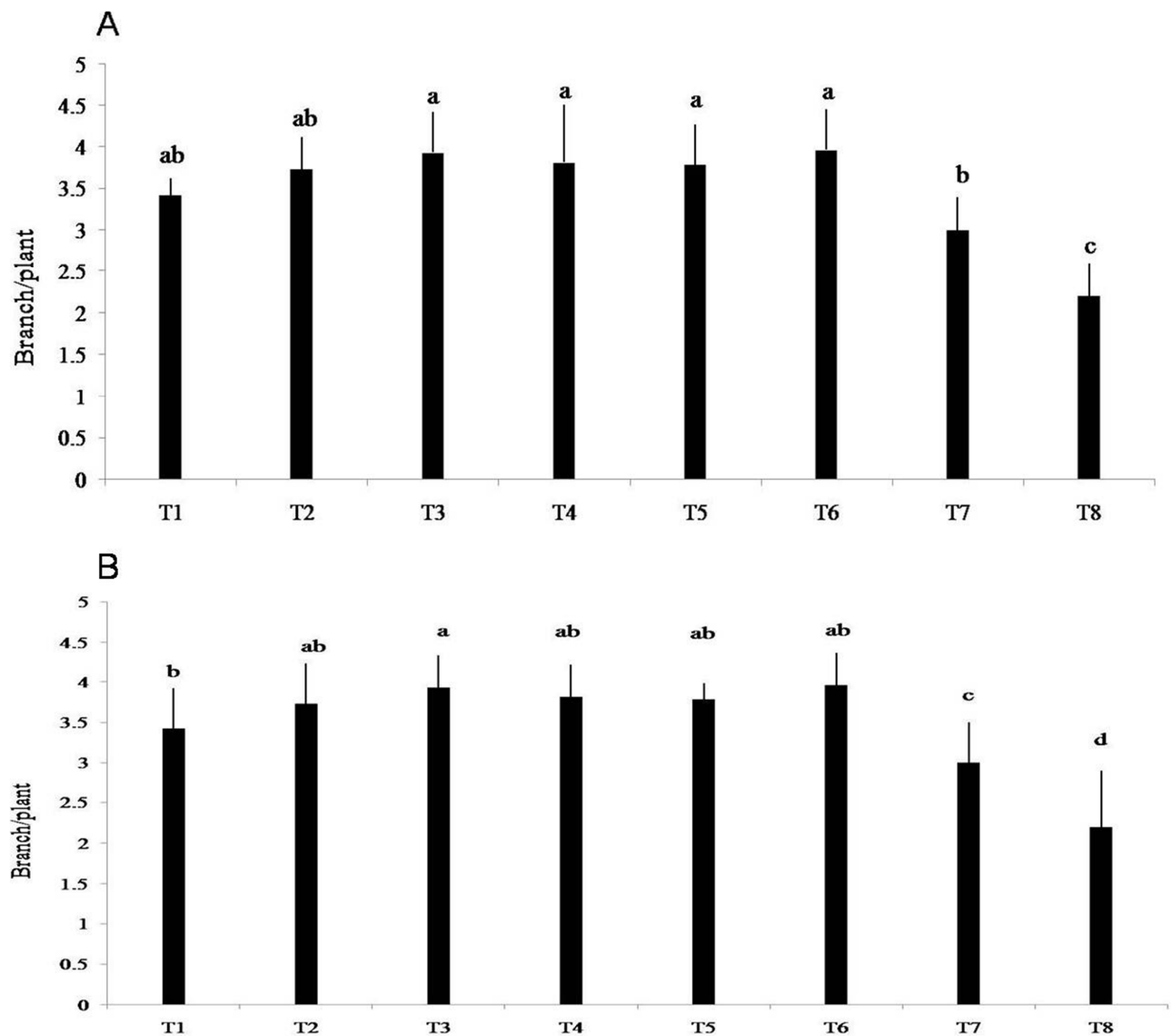

Figure 4. Branch per plant observation by different treatments.(A) O-9897 (B) O-72. The results are expressed as the mean \pm S. E. M and DMRT.
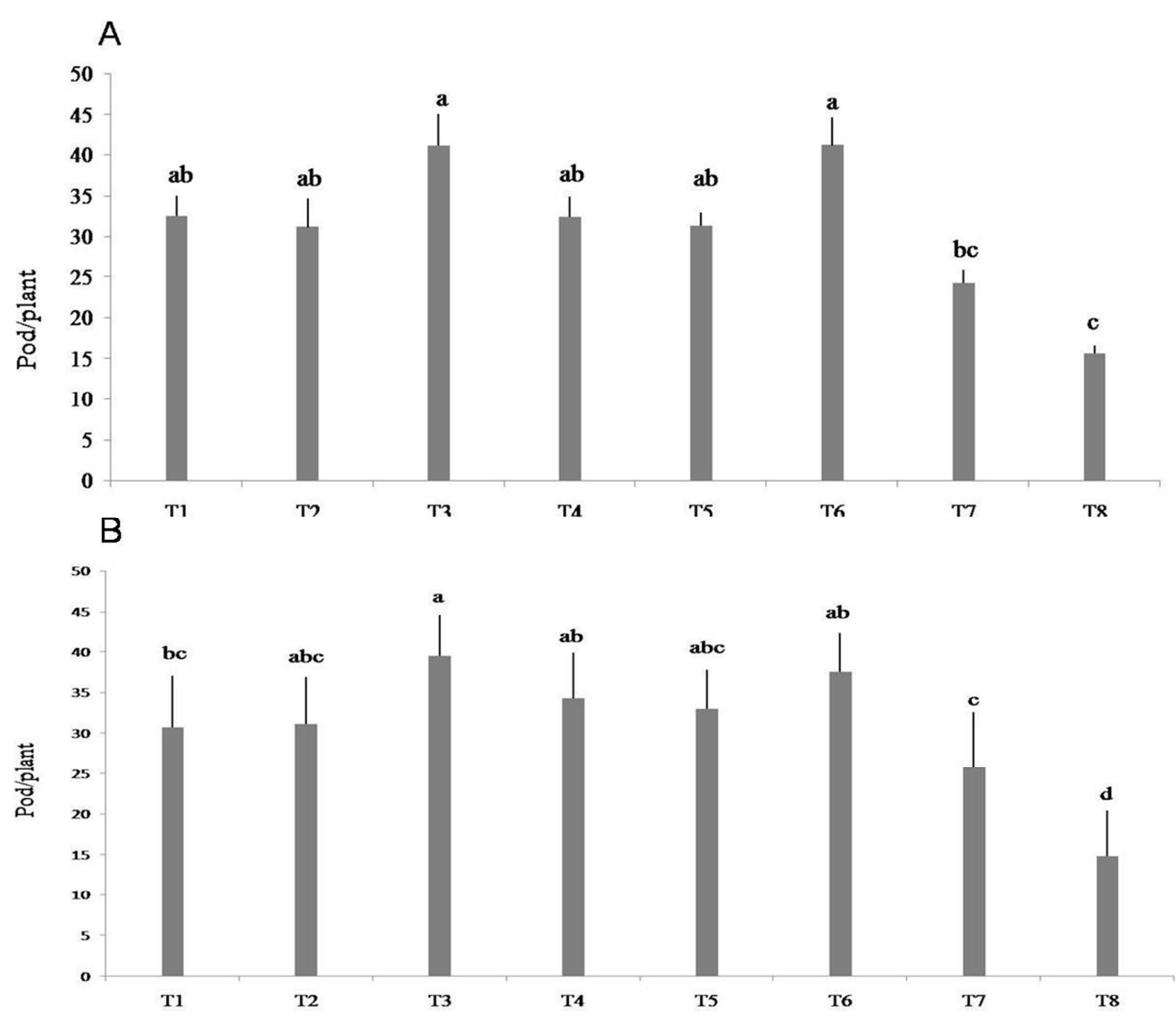

Figure 5. Pod per plant observation by different treatments. (A) $O-9897$ (B) O-72. The results are expressed as the mean \pm S. E. M and DMRT. 

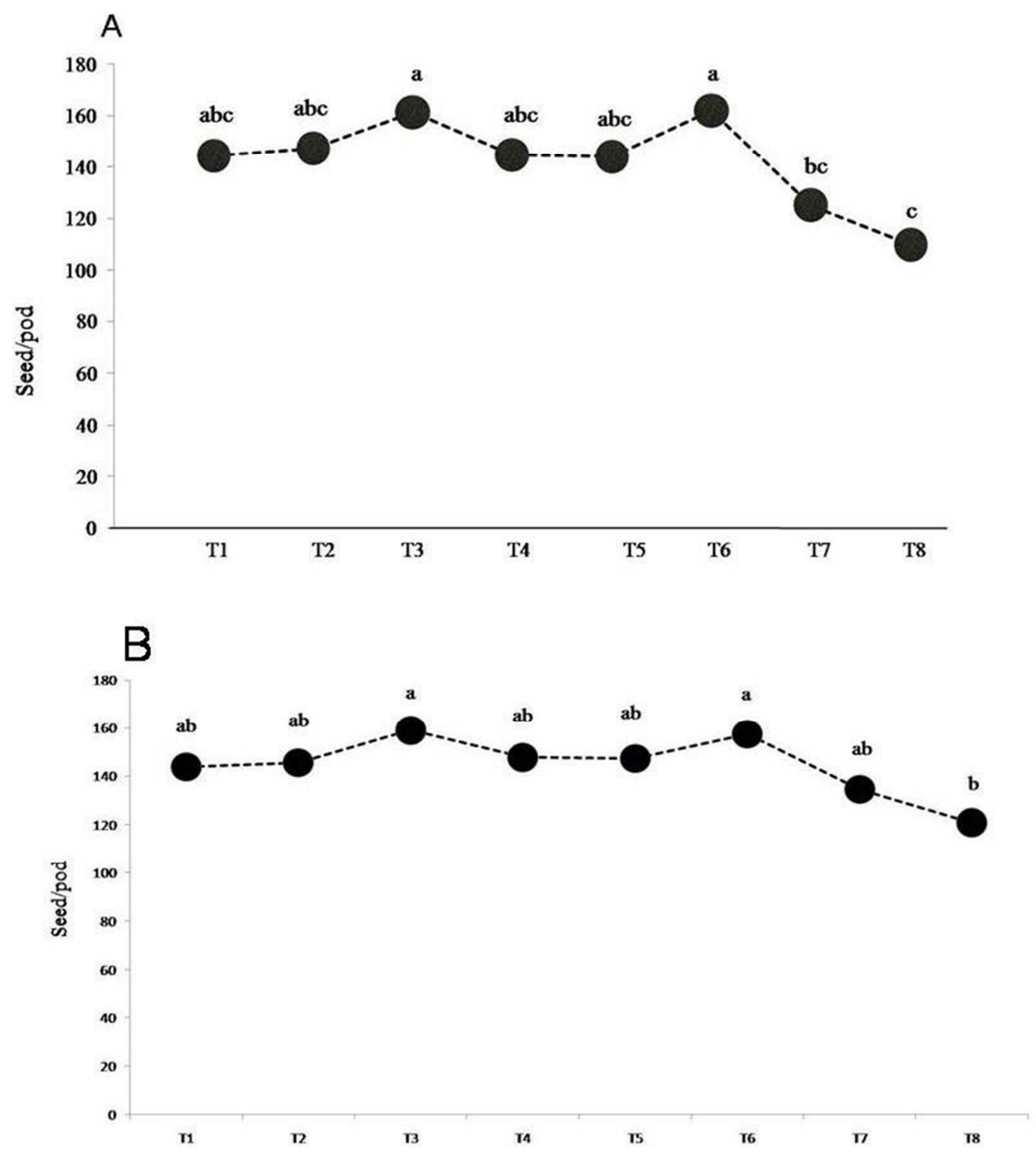

Figure 6. Seeds per podobservation by different treatments.(A) O-9897 (B) O-72. The results are expressed as the mean \pm S. E. M and DMRT.
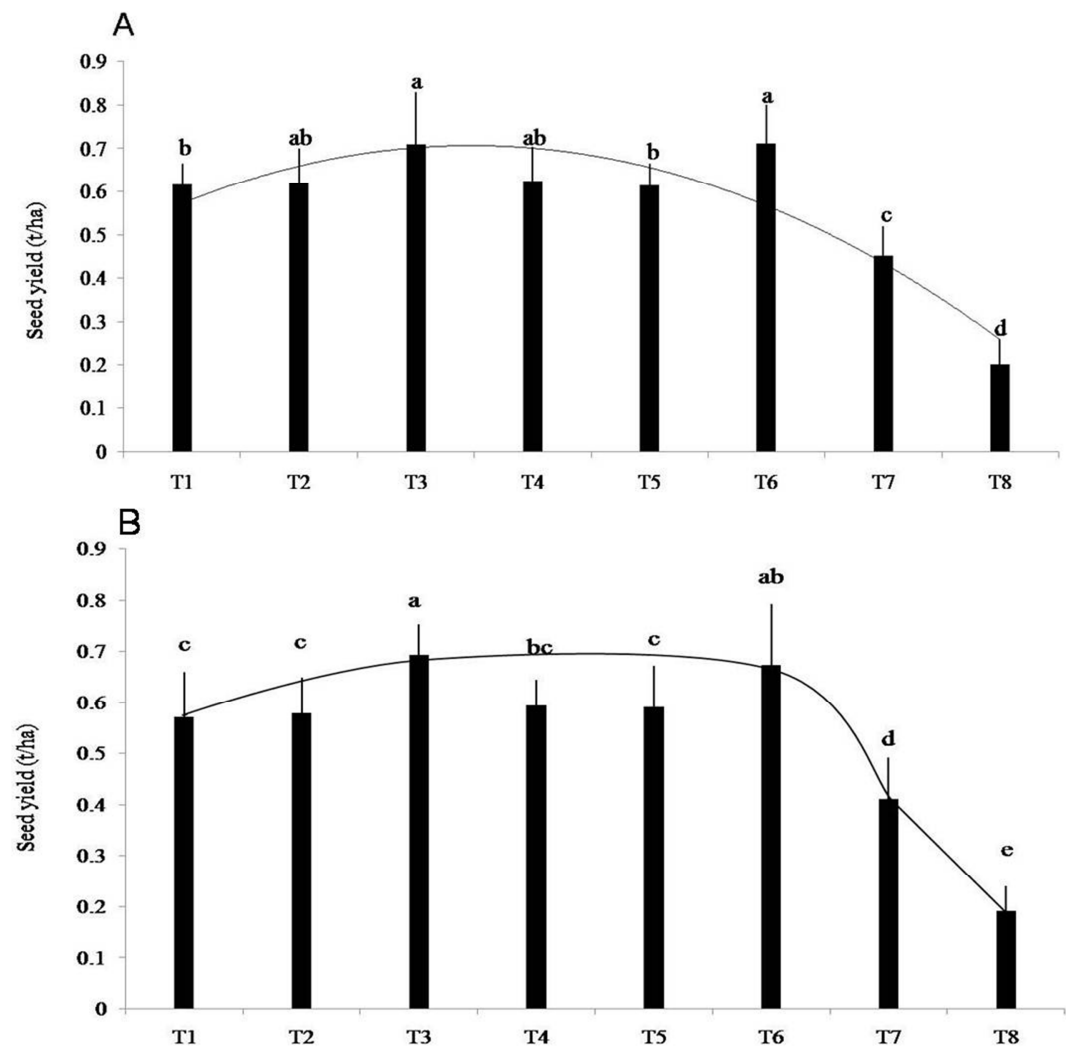

Figure 7. Seed yield observation by different treatments. (A) O-9897 (B) O-72. The results are expressed as the mean \pm S. E. M and DMRT. 
Number of pods/plant: $\mathrm{N}$ fertilizer application affects significantly the number of pods/plant. The significant highest number of pods/plant obtained having no significant difference in between the treatments $\mathrm{T}_{6}\left(\mathrm{~T}_{1}+25 \% \mathrm{NPK}\right)$ and $\mathrm{T}_{3}\left(\mathrm{~T}_{1}+25 \% \mathrm{NP}\right)$ per hectare. An increase in pods number by applying phosphatic fertilizer was observed [17-18].

Number of seeds/pod: Application of increasing doses of $\mathrm{N}$ fertilizer affect significantly the number of seeds/pod. Application of $\mathrm{T}_{6}\left(\mathrm{~T}_{1}+25 \% \mathrm{NPK}\right)$ and $\mathrm{T}_{3}\left(\mathrm{~T}_{1}+25 \% \mathrm{NP}\right)$ per hectare produced the highest number of seeds/pod. About 127 to 200 seeds in each fruit of C. olitorius L were reported [19].

Seed yield: Significant effect of additional N, P and K fertilizer application on seed yield was observed. In case of increasing doses of NPK fertilizer application, significantly high seed yield was observed with $\mathrm{T}_{6}\left(\mathrm{~T}_{1}+25 \% \mathrm{NPK}\right)$ and $\mathrm{T}_{3}\left(\mathrm{~T}_{1}+25 \% \mathrm{NP}\right)$ per hectare. $\mathrm{P} \& \mathrm{~K}$ application without $\mathrm{N}$, had little effect on jute [20]. In presence of $\mathrm{P}$ and $\mathrm{K}$ without $\mathrm{N}$, fibre yield markedly decreased below the yield obtained without fertilizer [21]. The results indicated that the plant height, number of branches per plant, number of pods per plant, number of seeds per pod had influence on seed yield. Higher seed yield from crops having higher number of branches per plant, number of pods per plant, number of seeds per pod and weight of 1000 seeds [22-25].

\section{Conclusion}

It may be concluded that the application of increasing doses of NPK fertilizer has significant effect on seed yield and yield contributing characters. However, the highest seed yield may be obtained with the application of $\mathrm{T}_{6}\left(\mathrm{~T}_{1}+25 \%\right.$ NPK $)$ or $T_{3}\left(T_{1}+25 \% \mathrm{NP}\right)$ per hectare in Bangladesh.

\section{Authors' Contribution}

Ali, M. S. designed and performed research, analyzed data and wrote the manuscript; Hoque, M. M. \& S. Shahanaz performed research and analyzed data; Gani, M. N. supervised the research; and Islam, M. M., supervised and edited the first draft of the manuscript.

\section{Conflict of Interest}

The authors declare that they have no competing interests.

\section{Acknowledgements}

This research work was fully supported by revenue budget of Bangladesh Jute Research Institute, Ministry of Agriculture, Bangladesh. The author deeply expressed his gratitude to Chief Scientific Officers of BJRI-Md. AKM Farukuzzaman, Mrs. Suraiya Khandker, Mrs. Kishwar Sultana, Dr. AKM Maqsudul Alam and Director General of BJRI for their inspiration and kind support. The author also expressed gratitude to all personnel of Agronomy Division
BJRI for their contribution regarding this program

\section{References}

[1] Hossain, M. A. F. A. Talukder, H. Islam; G. Morshed and A. Khan, 1994, Seed Production through transplanting Jute Seedling. Ann. Rep.(1992-94). Bangladesh Jute Res. Inst. Dhaka.

[2] Hillin C. K. and Hudak P. F.2003. Nitrate contamination in the seymouraquifer, north central texas, USA. Bull. Enviro. Contam. Tox. 70: 674-679.

[3] De Paz J. M. and Ramos C. 2004. Simulation of nitrate leaching for different nitrogen fertilization rates in a region of Valencia (Spain) using a GISGLEAMS system. Agr. Ecosyst. Environ. 103: 59-73.

[4] Alam M. M., Ladha J. K., Foyjunnessa. Rahman Z., Khan S. R., Harun-ur-Rashid. Khan, A. H. and Buresh R. J. 2006. Nutrient managementfor increased productivity of ricewheat cropping system in Bangladesh Field Crop. Res. 96, 374-386.

[5] Dambreville C., Morvan T. and Germon J. C.2008. $\mathrm{N}_{2} \mathrm{O}$ emission in maize-crops fertilized with pig slurry, matured pig manure or ammonium nitrate in Brittany. Agr. Ecosyst. Environ. 123: 01-210.

[6] Mugwe J., Mugendi D., Kungu J. and Mucheru-Muna M. M. 2009. Maize yields response to application of organic and inorganic input under on-station and on-farm experiments in central Kenya. Expl. Agric. 45: 47-59.

[7] Mucheru-Muna M. W., Pypers P., Mugendi D., Kung'uJ., Mugwe J., Merckx R., and Vanlauwe B.2010. A staggered maize-legume intercrop arrangement robustly increases crop yields and economic returns in the highlands of Central Kenya. Field Crops Research. 115: 132-139.

[8] Mucheru-Muna M. W., Mugendi D., Pypers P., Mugwe J., Kung'u J., Vanlauwe B., and Merckx R. 2014. Enhancing maize productivity and profitability using organic inputs and mineral fertilizer in central Kenya small-hold fields. Experimental Agriculture. 50: 250-269.

[9] More S. M. and Pacharne D. P. 2017. Seed yield and economics of jute (Corchorus olitorius) as influenced by different dates of sowing, spacing and topping management. International Journal of Agricultural Sciences, 13 (1): 20-24.

[10] Patra K., Poddar P. and Mitra B. 2016. Effect of varying levels of fertility on seed production of various olitorius jute varieties in teraizone of West Bengal. Journalof Crop and Weed, 12 (2): 65-67.

[11] Ambika S., Manonmani V. and Somasundaram G. 2014. Review on effect of seed size on seedling vigour and seed yield. Research Journal of Seed Science, 7 (2): 31-38.

[12] Singh, A. P., D. M. Ganguly and S. L. Basak, 1984. Effect of spacings and sowing dates on jute seed yield. Seed Res., 1293: $87-91$

[13] Hossain, A. M., M. Islam, A. M. Ahad, G. Rabbany and N. Zaman, 1992. Improvement of seed production technology. Annual Report Bangla. Sher-e-Bangla Nagar, Dhaka 1207, Bangladesh, pp: 150-151. 
[14] Islam, R., S. Iqbal, A. Rahman and M. L. Rahman, 1994 Comparative study of four different methods of jute seed production. Bangladash J. Fibre Res., 19: 27-27.

[15] Gomez, K. A. and A. A. Gomez, 1984. Statistical Procedures for Agricultural Research. 2nd Edn., John Wiley and Sons Inc., New York, USA., pp: 13-175.

[16] Ali, M. M., M. I. Ali and M. K. Khan, 1990. Effect of fertilizer on the growth and yield of wheat in red brown terrace soils of Bangladesh. Bangladesh J. Soil Sci., 21: 13-17.

[17] Das, H. N., 1982. Effect of nitrogen, phosphorus, potassium and calcium on growth and yield of groundnut. J. Res. Assam. Agric. Univ., 3: 15-18.

[18] Juan, A. R., L. J. Curayag and H. M. Pava, 1988. Influence of phosphorus fertilizers on pod yield and seed quality of three peanut varieties (Arachis hypogaea L.) CUM. J. Agric. Food Nutr., 1: 33-62.

[19] Kundu, B. C., K. C. Basak and P. B. Sarcar, 1959. Jute in India. Jute Agriculture Research Institute, Calcutta, India.

[20] Sen, P. K. and K. I. Banerjee, 1960. Physiological studies in jute: 1. Effect of N, P and K on the growth of jute (C. olitorius var. C. G.). Indian Agric., 4: 121-121.

[21] Alam, A. K. M. M., M. M. Alam, P. B. Mandal and M. A. K. Majlis, 1988. Responsiveness of newly released FulgoniTossa (Chorcorusolitorius L.) variety to $\mathrm{N}, \mathrm{P}$ and $\mathrm{K}$ fertilizer application. Bangladesh J. Jute Fib. Res., 13: 35-38.

[22] Hossain, M. A. and M. A. Wahhab, 1980. Effect of intercropping aus and kaon (Foxtail millet) with capsularis jute seed crop on yield and return. Bangladesh J. Jute Fib. Res., 5: 35-40.
[23] Khatun, R. and M. A. Sobhan, 1985. Correlation between fibre yield and other plant characters in white jute (Corchorus capsularis of Bangladesh). Bangladash J. Agric., 10: 9-16.

[24] Talukder, F. A. H. and M. A. Hossain, 1989. Response of Chorcorus capsularis L. to seed yield. Bangladesh J. Jute Fib. Res., 14: 31-35.

[25] Ali, M. S., Hossen, M., Ahmed, B., Gani, M. N., Islam, M. M, 2017. Jute Seed Yield Response to Irrigation and Nitrogen Fertilization in Field-Grown Environment. American Journal of Agricultural Science. 4(6):149-153.

\section{Biography}

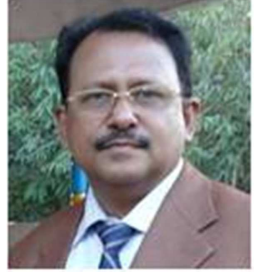

Md Mahbubul Islam awarded $\mathrm{PhD}$ in 2008 from the Department of Agronomy of Bangladesh Agricultural University especially on Jute seed quality, plant establishment and yield. He had done his M.Sc. (Agriculture) in Agronomy and B.Sc. Agriculture (Hons.) from Bangladesh Agricultural University. He is working at Bangladesh Jute Research Institute (BJRI) since 1989. He is serving as Chief Scientific Officer \& Head of Agronomy Division. He has 6 books, 80 scientific papers and more than 75 popular articles published in international and national journals, newsletters etc. He visited United Kingdom, Malaysia, and India for training, seminar, workshop purpose. 